\title{
簡易微小静電容量測定法と変位および 振動振幅測定への応用
}

\author{
菊 池 清 明*・鈴 木 昭** \\ Simple Method for Measuring Small Capacitance and Its Applications \\ to Displacement and Vibrating Amplitude Measurement
}

Kiyoaki KıкuCHI* and Akira Suzuri**

\begin{abstract}
A capacitance-to-voltage converter is discrived for measurement of small capacitance. This method can be measured at audio frequency ranges and is not affected very much with a stray capacitance which come out between a ground and unknown capacitor. The sensitivity can set extensively by choosing magnitude of the feedback capacitance and the signal voltages.

As application of the $\mathrm{C}-\mathrm{V}$ converter, we have developed a displacement meter and a vibrating amplitude meter. The sensitivities of these instruments were obtained $51.6 \mathrm{mV} / \mu \mathrm{m}$ with displacement meter and $2.52 \mathrm{mV} / \mu \mathrm{m}$ with vibrating amplitude meter when an effective diameter of the probe was $2.2 \mathrm{~mm}$.
\end{abstract}

Key Words : capacitance-to-voltage converter, capacitor meter, capacitance sensor, displacement meter vibrating amplitude meter

\section{1. まえがき}

微小変位および微小振動振幅の測定にレーザー干渉 法を利用する方法が，高感度を有するてとから最近広 く，用いられてきた．しかしての方法は構成が複雑で セッティングおよび測定に熟練を必要とする欠点を有 する. 一方コンデンサセンサは構造が簡単で取扱いが 容易であり比較的高感度が得られる利点を有するが, 工業的に広く利用しようとすると簡単でしかも容易に

†電気学会計測研究会で発表 (昭 $58 \cdot 11$ )

* 東京職業訓練短期大学校 小平市小川西町 2260

** 神奈川大学工学部 横浜市神奈川区六角橋 3-27

* Tokyo Vocational Training College, Kodaira

** Faculty of Engineering, Kanagawa University Yokohama

(Received March 15, 1984)

(Revised July 31, 1984)
利用できる回路が少ない難点がある.

一般に静電容量の值が小さくなるにつれて, 端子接地間の分布容量による誤差が増加してくる. そこで 被測定容量を三端子コンデンサ構造と考え, 分布容量 および漏洩抵抗が無視できる計測法 ${ }^{12}$ でなければなら ない，一方回路的な面加あ取扱いの面からむ，使用 周波数は低いほうが便利である. 筆者らは可聴周波数 でしかも感度が自由に調節可能な簡易微小静電容量測 定装置を開発し, 変位計 ${ }^{23}$ 抢よび振動振幅測定装置 ${ }^{374}$ の試作を行った結果について述べる.

\section{2. 測 定原理}

Fig. 1 は簡易微小静電容量測定回路の原理図を示 したあので, 容量一電圧変換回路と点線内の三端子コ ンデンサとして表わした被測定容量 $C_{x}$ とで構成され る. $C_{1}, C_{2}$ は被測定容量 $C_{x}$ の端子と接地間の分布容 量で $R_{1}, R_{2}$ 㹥漏洩抵抗である. $C_{1}$ およよ゙ $R_{1}$ は発 振器の内部インピーダンスが十分小さいとすれば， こ れらに流れる電流による電圧降下は無視できる。 $G$ は 高入力抵抗演算增幅器の利得で $C_{g}^{\prime}$ は入力容量, $R_{\theta}^{\prime}$ は 入力抵抗である. $C_{f}$ を帰還容量とし, 入力電圧 $e_{i}$ が印加されたときの出力電圧 $e_{0}$ は $C_{g}=C_{o}^{\prime}+C_{2}, R_{q}$ $=R_{2} / / R_{g}^{\prime}$ として

$$
-e_{o}=\frac{j \omega G R_{g} C_{x}}{j \omega R_{g}\left\{(1+G) C_{f}+C_{g}+C_{x}\right\}+1} \cdot e_{i}
$$

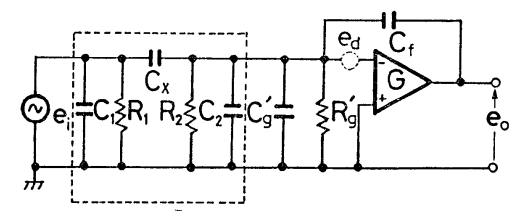

Fig. 1 Capacitance-to-voltage converter circuit. (C-V converter circuit) 
となる. とてで利得 $G$ が十分大きく $C_{f} \gg\left(C_{\theta}+C_{x}\right) / G$, $\left(\omega G R_{\theta} C_{f}\right)^{2} \gg 1$ が成立すれば(1) 式は，

$$
-e_{0} \fallingdotseq \frac{C_{x}}{C_{f}} \cdot e_{i}
$$

と簡単に表わすととができ，分布容量および漏洩抵抗 の影響は無視できる．また $C_{x}$ の值は， $C_{f}, e_{i}$ の選定 により広範囲に求めることができる．乙の回路の低域 遮断周波数 $f_{L}$ は

$$
f_{L}=\frac{1}{2 \pi G R_{\ell} C_{f}}
$$

で与えられる。一方高域遮断周波数 $f_{H}$ は増幅器の周 波数特性を $G(\omega)=G_{0} /(1+j \omega / \omega H 0)$ とし, $C_{f} \gg\left(C_{\vartheta}+\right.$ $\left.C_{x}\right) / G_{0}, \omega H_{0} R_{g} C_{f} G_{0} \gg 1, \omega R_{g} C_{f} G_{0} \gg 1\left(K=\left(C_{g}+C_{x}\right) /\right.$ $\left.C_{f}\right)$ とすると，

$$
f_{H} \fallingdotseq \frac{f_{H 0} \cdot G_{0}}{1+K}\left(f_{H 0}=\frac{\omega_{H 0}}{2 \pi}\right)
$$

で与えられる. 以上は容量－電圧回路の帯域特性を述 べたあのであるが，Fig. 1 の回路では直流に対する負 州還がないために演算増幅器自体のドリフトによって 直流レベルが変動してしまう．乙の回路に仮に図の点 線で示したようなドリフト電圧 $e_{d}=E_{d} \cdot u(t)$ が加わっ たとしたときのドリフト利得を求めると,

$$
\left|\frac{e_{o}}{E_{d}}\right| \fallingdotseq 1+K+\frac{t}{C_{f} \cdot R_{g}} \quad\left(K=\frac{C_{g}+C_{x}}{C_{f}}\right)
$$

となり，したがってドリフト補償が必要となる。ドリ フト補償法にはたとえば，静電容量および変位の測定 のように単一周波数で使用する場合（簡易法と呼ぶ）

と, 振動振幅測定のごとく広帯域に渡る場合（広帯域 法と呼ぶ)とが考えられる．Fig. 2 は単一信号周波数 で用いる場合の簡易ドリフト補償回路を示したあの で，抵抗 $R_{f}$ で直流負帰還を行った回路である. $G 》$ $1, C_{f} \gg\left(C_{\theta}+C_{x}\right) / G, . R_{\theta} \gg R_{f} / G$ の条件で出力電圧 $e_{o}$ は

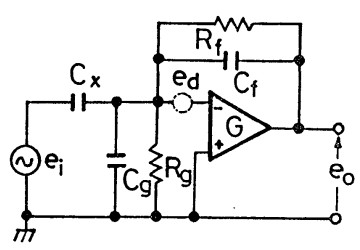

Fig. 2 Simple drift compensated $\mathrm{C}-\mathrm{V}$ converter circuit

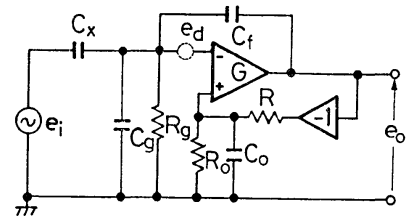

Fig. 3 Wide-band drift compensated $\mathrm{C}-\mathrm{V}$ converter circuit

$$
-e_{o} \fallingdotseq \frac{j \omega R_{f} C_{x}}{j \omega R_{f} C_{f}+1} \cdot e_{i}
$$

で与えられる.とこで信号周波数に対して，

$$
\left(\omega R_{f} C_{f}\right)^{2} \gg 1
$$

が満足されるように各定数を選べば，（6)式は（2)式 と同一となる. この回路のドリフト電圧 $e_{d}=E_{d} \cdot u(t)$ に対するドリフト利得を求めると，

$$
\left.\begin{array}{l}
\left|\frac{e_{o}}{E_{d}}\right| \fallingdotseq 1+N+(K-N) \exp \left(-\frac{t}{\tau_{1}}\right) \\
\tau_{1}=R_{f} C_{f}, N=R_{f} / R_{g}, K=\left(C_{g}+C_{x}\right) / C_{f}
\end{array}\right\}
$$

となり，初期值は基本回路と同様に $(1+K)$ であり最 終值は $(1+N)$ となる. 高入力抵抗演算増幅器を用い れば一般に $R_{g}>R_{f}$ が成立するのでドリフト利得に ついては $(1+K)$ に注目することになる，低減遮断周 波数は,

$$
f_{L} \fallingdotseq \frac{1}{2 \pi \tau_{1}}=\frac{1}{2 \pi R_{f} C_{f}}
$$

で与えられた Fig. 4 亿直線 $P$ として計算值を示した.

Fig. 3 は広帯域法で利得 1 の反転増幅器と $R, R_{0}$, $C_{0}$ より構成される低域通過フィルタで低周波数の負 帰還を行ったすのである. 出力電圧 $e_{o}$ は $G \gg 1, C_{f} 》$ $\left(C_{g}+C_{x}\right) / G, R_{0} \gg R / G$ とすれば,

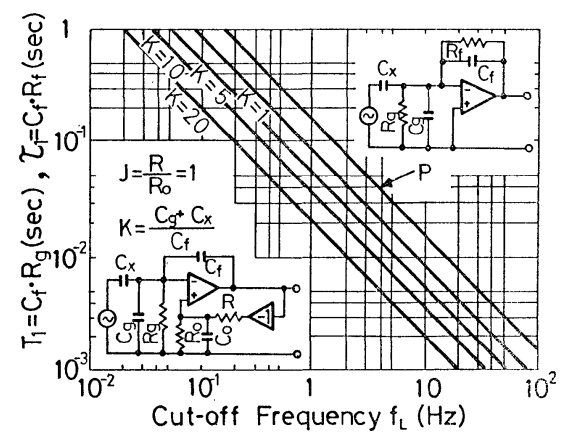

Fig. 4 Relation between $T_{1}$ or $\tau_{1}$ and low cut-off frequency $F_{\boldsymbol{L}}$ to various values of $K$

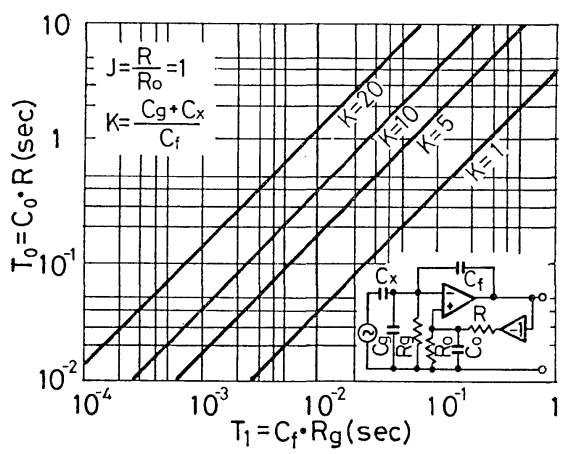

Fig. 5 Relation between $T_{0}$ and $T_{1}$ to various values of $K$ 


$$
\begin{aligned}
-e_{0} \fallingdotseq & \frac{(j \omega)^{2} R_{g} R C_{0} C_{x}+j \omega R_{g} C_{x}(1}{(j \omega)^{2} R_{g} R C_{0} C_{f}+j \omega R_{g}\left\{C_{f}\left(2+R / R_{0}\right)\right.} * \\
& * \frac{\left.+R / R_{0}\right)}{\left.+C_{g}+C_{x}\right\}+1} \cdot e_{i}
\end{aligned}
$$

となる. ここで変数 $j \omega$ について分母が重根となる条 件を最適補償として求めると。

$$
\begin{gathered}
T_{1}=\frac{4 T_{0}}{(2+J+K)^{2}}\left(T_{0}=C_{0} R, T_{1}=C_{f} R_{\theta},\right. \\
\left.J=\frac{R}{R_{0}}, K=\frac{C_{g}+C_{x}}{C_{f}}\right)
\end{gathered}
$$

の関係が必要となり，ここで

$$
\left(\omega \cdot \frac{2 T_{0}}{2+J+K}\right)^{2} \gg 1
$$

のように各定数を選べば，(10)式は (2) 式と等しくな る.ドリフト利得は

$$
\begin{aligned}
& \left|\frac{e_{o}}{E_{d}}\right| \fallingdotseq(1+J)\left[1-\left\{1-\frac{1+K}{1+J}+\frac{(K-J)^{2}}{4 T_{0}(1+J)} \cdot t\right\}\right. \\
& \left.\quad \exp \left(-\frac{t}{\tau_{2}}\right)\right] \\
& \tau_{2} \fallingdotseq \frac{2 T_{0}}{2+J+K}=\frac{T_{1}(2+J+K)}{2}
\end{aligned}
$$

となり, 初期值は基本回路と同様に $(1+K)$ で, 最終 值は $(1+J)$ となる.

回路の設計法は許容できるドリフト利得を考慮し て, 要求される低域遮断周波数 $f_{L}$ より $T_{1}, T_{0}$ の值 を求める. Fig. 4 は長時間ドリフトを考慮して $J=1$, $K$ をパラメータとして $f_{L}$ と $T_{1}$ の関係を示したも ので, Fig. 5 は(11)式の関係を示したものである.

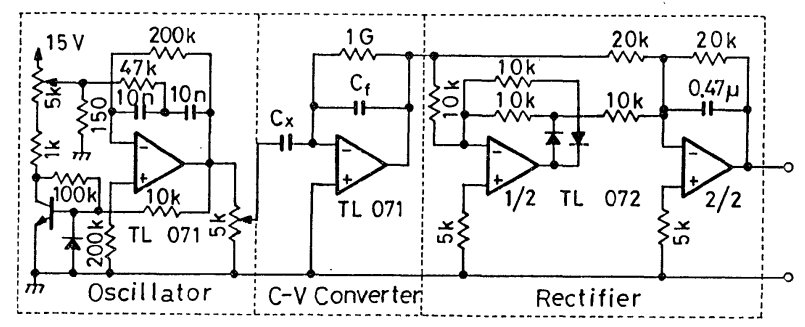

Fig. 6 Circuit diagram of the capacitor meter

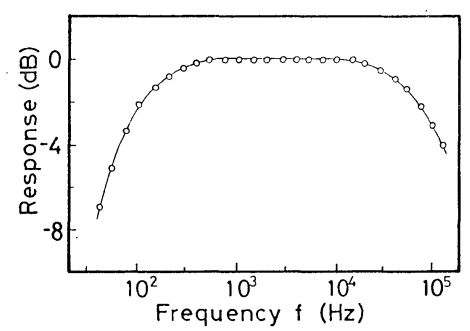

Fig. 7 Frequency characteristics of a simple drift compensated $\mathrm{C}-\mathrm{V}$ converter circuit

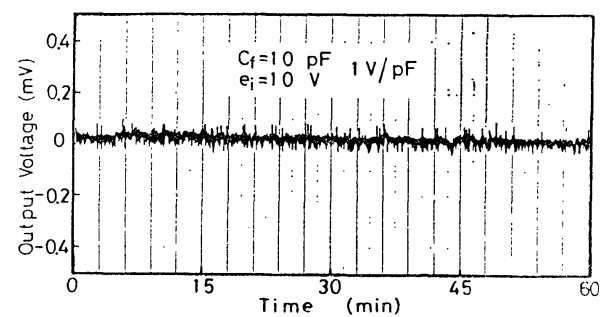

Fig. 8 Drift characteristics of capacitor meter

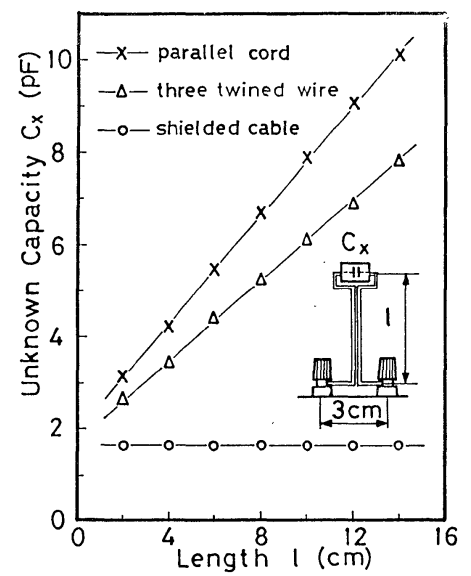

Fig. 9 Experimental results to several lead-wires

以上の計算結果より $K>1$ にすれば広帯域法は簡易法 より $f_{L}$ を低くするととができるが，短時間ドリフト の增加はまぬがれない。

\section{3. 回路亡特性}

Fig. 6 は試作した微小静電容量測定装置の 回路図を示したもので，発振回路，容量－電圧 変換回路および整流回路より構成される.容 量，変位などの測定に対しては単一周波数で測 定する関係上簡易ドリフト補償法を採用し， $R_{f}=10^{9} \Omega$ を用いた. Fig. 7 は $C_{f}=2.32 \mathrm{pF}$ としたときの周波数特性を示したもので低域遮 断周波数 $f_{L}$ は $70 \mathrm{~Hz}$, 高域遮断周波数 $f_{H}$ は $97 \mathrm{kHz}$ である. これより使用周波数は $5 \mathrm{kHz}$ に設定した. とのとき $\left(\omega C_{f} R_{f}\right)^{2}=5.3 \times 10^{3}$ となり (7) 式を十分満足している. Fig. 8 は pF 程度の静 電容量を測定するための回路に対するドリフト特性を 示したもので $C_{f}=10 \mathrm{pF}, e_{i}=10 \mathrm{~V}$ である. 長時間ド リフトは良好に補償されほとんど無視できる．短時間 ドリフトについては約 $\pm 25 \mu \mathrm{V}$ 程度生じているが, 静電容量に換算すると $\pm 25 \mathrm{aF}$ の変動に相当する. 試作した装置において测定端子間距離 $3 \mathrm{~cm}$ とし, 被 測定用コンデンサとして表示值 $2 \mathrm{pF}$ のスチコンを用 


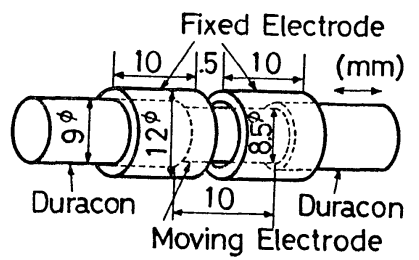

Fig. 10 Shape and dimensions of displacement sensor

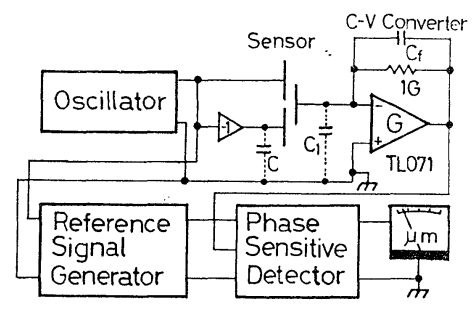

Fig. 11 Block diagram of the displacement meter

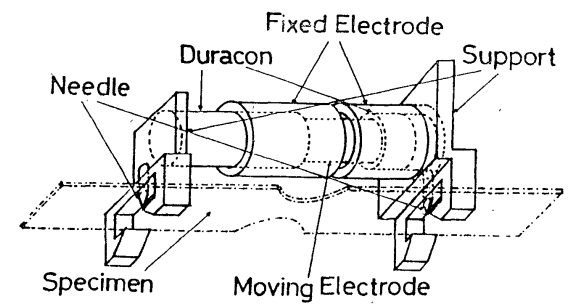

Fig. 12 Tool used to fix the sensor on specimen

い,リード線として平行ビニール線, 三つ編線および $1 \mathrm{~cm}$ 当り約 $2.2 \mathrm{pF}$ のシールド線の 3 種類を用い, リード線の影響を調べた． Fig.9 はリード線長と測 定された容量との結果で, 平行ビニール線, 三つ編線

(三つ編線の内 2 本は測定用端子に 1 本は接地に接続 した）を用いた場合 $l$ の増加と共に $C_{x}$ が直線的に増 加しており，分布容量の影響を大きく受け正確に $C_{x}$ を測定することが困難であるが，シールド線を用いた 場合では $C_{x}$ がリード線の長さに無関係となり $C_{x}$ が 正確に求まるととを示している.

\section{4. 変位および振動振幅測定への応用}

\section{1 変位測定}

変位測定用センサには距離変化に対し容量が直線的 に変化する同心円筒コンデンサを用い，Fig. 10 に試 作したセンサ（変位 $\pm 5 \mathrm{~mm}$ ) の寸法および形状を示 した. 二つの固定電極に逆位相の信号を加え差動コン デンサを構成している. 試作した可動電極の移動量 $\Delta l$ と容量変化分 $\Delta C$ の関係は $\Delta C / \Delta l=1.95 \times 10^{-9}$ F/m である. Fig. 11 は変位計のブロック図で, セン

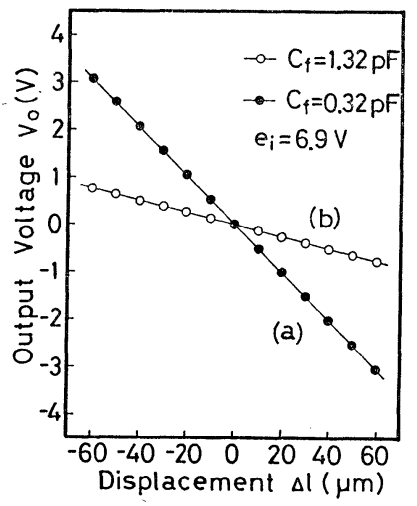

Fig. 13 Relation between output voltage $V_{0}$ vs. displacement $\Delta l$

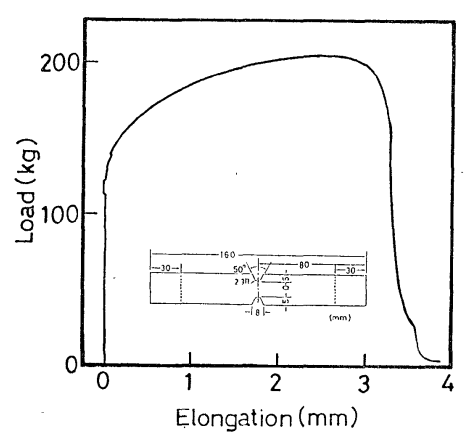

Fig. 14 An example of usage. (relation between load vs. elongation)

サに加える逆相電圧は利得 1 の反転増幅器を用いた. センサからのリード線は可動電極にシールド線を用 い, 片方の固定電極を通して外部に出した. その際生 ずる分布容量を $C_{0}, C_{1}$ としたとき, $C_{f} 》\left(C_{x}+C_{g}\right) /$ $G,\left(C_{g}=C_{1}+C_{g}^{\prime}\right)$ が成立する範囲内では誤差は無視で きる. また $C_{0}$ は電源のインピーダンスが十分小さい ので問題とならない，容量－電圧変換回路の出力は移 動方向による極性をもたせるために同期整流した後電 圧計で指示させた. 今回は引張試験用板状試料の引張 長さの測定用変位計を目的としているため, 移動電極 と固定電極を Fig. 12 に示すような治具で固定した. 試料の片面を針状のビスで固定し測定上の標点を出し ている．簡易ドリフト補償をした容量－電圧変換回路 は分布容量の影響を少なくするためセンサの上に直接 取り付け，その迴りにシールドを施した. Fig. 13 は 信号源電圧 $e_{i}=6.9 \mathrm{~V}$ とし帰還容量 $C_{f}$ をパラメー タとしたときの変位 $\Delta l$ に対する感度を示したもので ある.（a）は $C_{f}$ として分布容量だけの結果で 51.6 $\mathrm{mV} / \mu \mathrm{m},(\mathrm{b})$ は分布容量を含め $C_{f}=1.32 \mathrm{pF}$ のとき で $12.5 \mathrm{mV} / \mu \mathrm{m}$ である. Fig. 14 は試作した変位計 
の使用例であり，鉄鋼材の引張試験結果で， $X-Y \vee$ コーダで記録したものである．X軸に変位計の出力,

$Y$ 軸にロードセルの出力を示した伸び - 荷重曲線の一 例である。

\section{2 振動振幅測定}

Fig. 15 は振動振幅測定回路の基本回路構成を示し たもので， 2 種類の電源と容量 - 電圧変換回路および 除算回路より構成されている，測定はつぎの 2 回の操 作によって完了する．まずスイッチを 1 にセットしプ ローブと振動体間距離 $d_{0}$ を定量する，つぎにスイッ チを 2 にセットして振動振幅を求める.プ゚ローブとの 距離の設定には振動体が静止の状態でも振動している 状態でも可能である.

（1）プローブと振動体間距離の設定

振動体が振幅 $\Delta d$, 周波数 $f_{v}$ で正弦振動していると 仮定すると，プローブー振動体間の静電容量 $C_{x}$ はプ

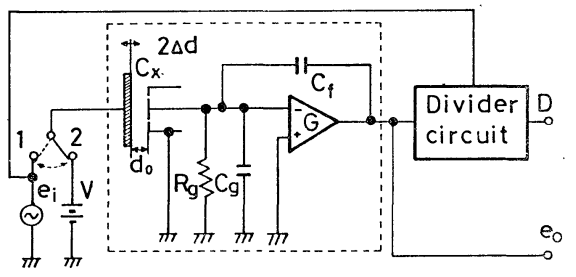

Fig. 15 Basic diagram of instrument to measuring the vibrating amplitude

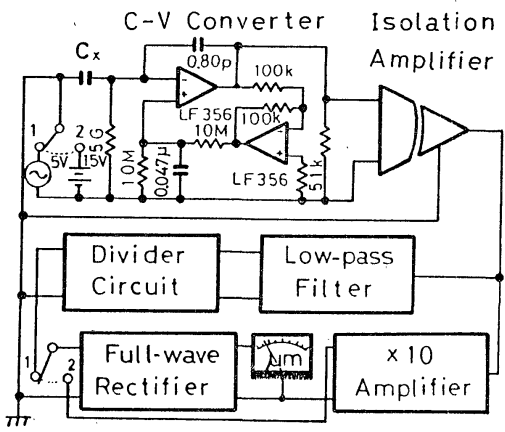

Fig. 16 Block diagram of the vibrating amplitude meter

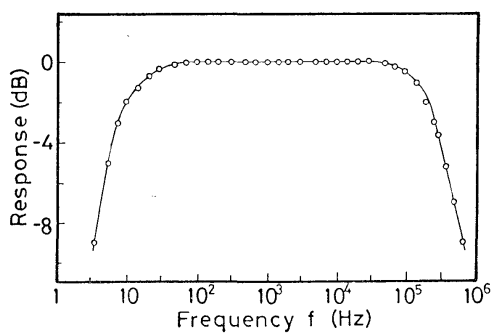

Fig. 17 Frequency characteristics of the vibrating amplitude meter
ローブの有効面積を $S$ とすると，

$$
C_{x}=\frac{\varepsilon_{0} S}{d_{0}} \cdot \frac{1}{1+\left(\Delta d / d_{0}\right) \cdot \sin \omega_{v} t}\left(\omega_{v}=2 \pi f_{v}\right)
$$

で与えられる.ただし $d_{0}$ は静止時におけるプロー ブ - 振動体間距離である. $\left(\Delta d / d_{0}\right) \ll 1$ の範囲内におい て $C_{x}$ は

$$
C_{x} \fallingdotseq \frac{\varepsilon_{0} S}{d_{0}} \cdot\left(1-\frac{\Delta d}{d_{0}} \sin \omega_{v} t\right)
$$

と置ける. ここでスイッチを 1 亿倒し振幅 $E_{0}$, 周波 数 $f\left(f<f_{v}\right)$ の交流信号 $e_{i}$ を加え, 低域通過フィル タで $f$ だけの信号を取り出すと,

$$
-e_{0} \fallingdotseq \frac{1}{k d_{0}} \cdot E_{0} \sin \omega t\left(k=\frac{C_{f}}{\varepsilon_{0} S}, \omega=2 \pi f\right)
$$

となり出力電圧 $e_{o}$ は $d_{0}$ に逆比例する. そこで入出 力の逆数を得るために除算器に加えれば, その出力 $D$ は除算器の利得を $Q$ とすると,

$$
D \fallingdotseq Q k d_{0}
$$

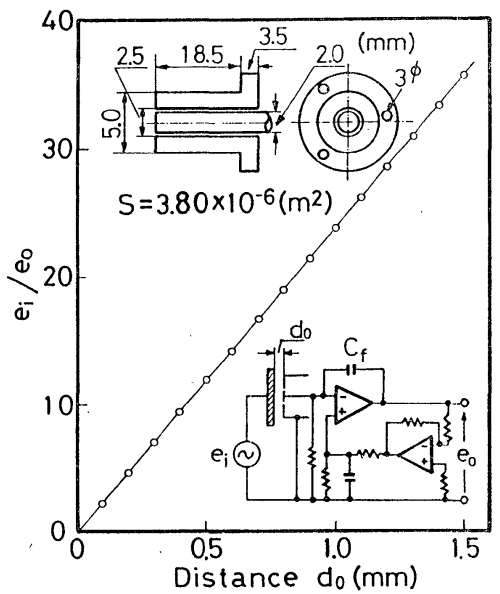

Fig. 18 Characteristics of the probe built as a trial

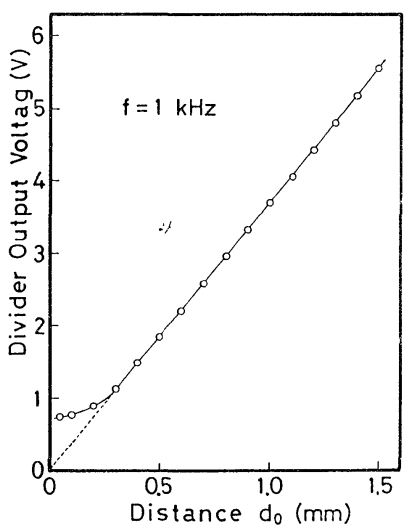

Fig. 19 Relation between divider output voltage vs. the distance between the probe and object vibrates 
となり， $S$ が一定の範囲内で $d_{0}$ に比例し， $D$ の值よ り距離 $d_{0}$ が求まる.

\section{(2) 振動振幅の測定}

つぎにプローブはそのままの位置でスイッチを 2 に セットし直流電圧 $\mathrm{V}$ を加える. このとき出力電圧 $e_{0}$ は $\left(\omega_{v} G C_{f} R_{q}\right)^{2} \gg 1$ が成立する範囲で

$$
-e_{o} \fallingdotseq \frac{V}{d_{0} k} \cdot \frac{\Delta d}{d_{0}} \sin \omega_{v} t
$$

となり最大值を $E_{m}$ とすると，

$$
\Delta d \fallingdotseq k d_{0}^{2} E_{m} / V
$$

となりそれぞれの值より $\Delta d$ が求まる.

Fig. 15 の回路では振動体が接地している 場合およ び接地したほうがよい場合には測定不能となる，そこ で容量 - 電圧変換回路自体を非接地とし, 絶縁増幅器 を経た後除算回路に加える方法により振動体を接地で きるようにした．Fig. 16 は $150 \mathrm{kHz}$ までの超音波 振動子の振動振幅測定用に試作した装置のブロック図

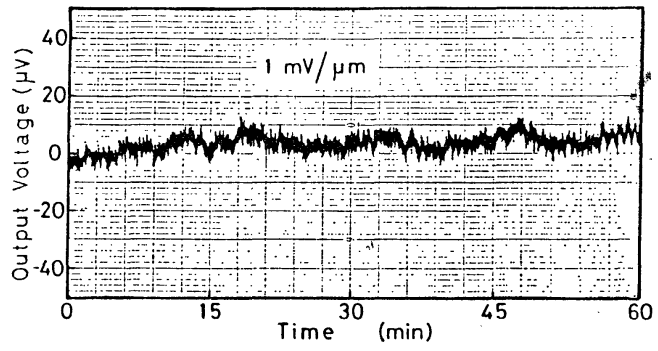

Fig. 20 Drift characteristics of the vibrating amplitude meter

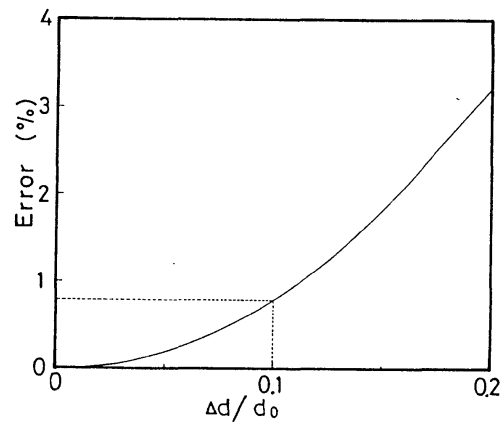

Fig. 21 Relation between error vs. $\Delta d / d_{0}$

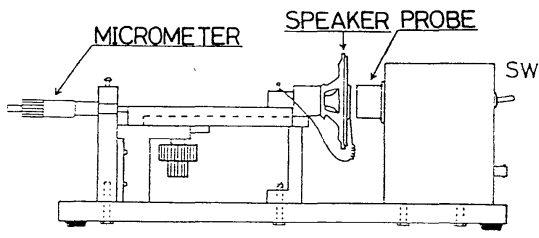

Fig. 22 Apparatus used to examine a characteristic of the vibrating amplitude meter
を示したもので, 容量一電圧変換回路には周波数範囲 を広く取るために広带域補償回路を用いた．Fig. 17 は絶縁增幅器後の周波数特性を示したすので，低域お よび高域遮断周 波数 $f_{L}, f_{H}$ はそれぞれ $10 \mathrm{~Hz}, 220$ $\mathrm{kHz}$ である. $C_{f}=0.80 \mathrm{pF}, R_{\vartheta}=5 \times 10^{9} \Omega$ に選定して あり, (13) 式の条件より被測定振動周波数の低限は,

Fig. 23 An example usage
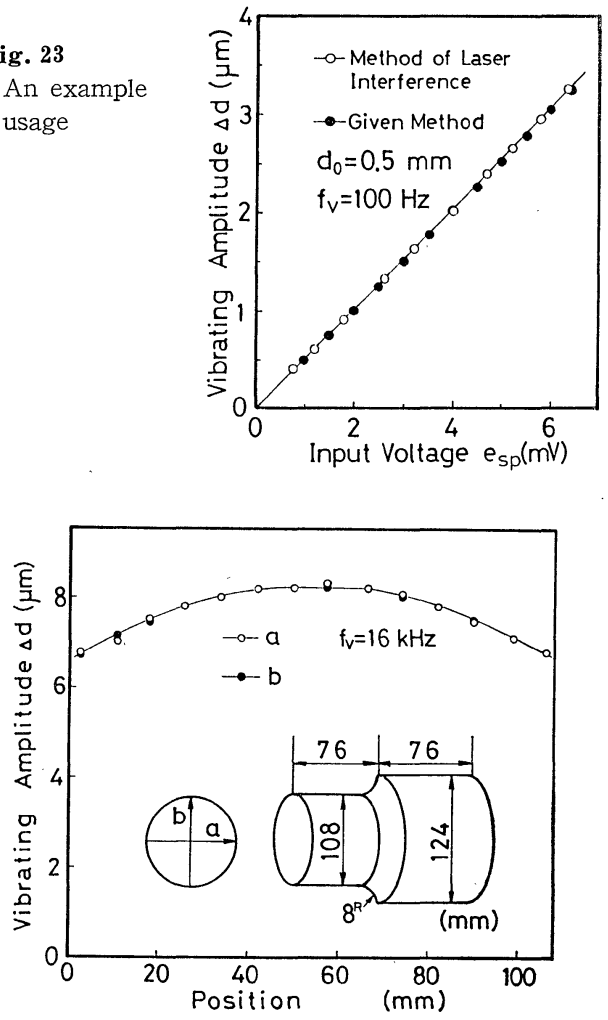

(a) Circular horn

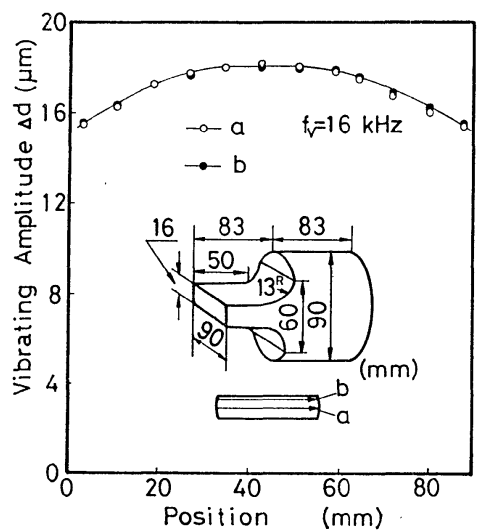

(b) Rectangular horn

Fig. 24 Examples were measured vibrating amplitude on the surface of a horn used to a ultrasonic machine tool 
許容誤差を $1 \%$ とすると約 $40 \mathrm{~Hz}$ となる. Fig. 18 は 試作したプローブの構造および寸法とプローブ試料間 距離 $d_{0}$ に対する入出力の逆比 $\left(e_{i} / e_{0}\right)$ を求めたすの で傾斜が $k$ である. 結果より $d_{0}=1.0 \sim 1.5 \mathrm{~mm}$ の範 囲内で直線関係を有し，プローブの有効面積 $S$ が一 定であるととを示している. 直線の傾きにより $k=$ $2.38 \times 10^{-4} \mathrm{~m}^{-1}, S=3.86 \times 10^{-6} \mathrm{~m}^{2}$ となる. プローブー 振動体間に加える交流信号 $e_{i}$ は， $5 \mathrm{~V}, 1 \mathrm{kHz}$ を用 いた. Fig. 19 は除算器の特性で $d_{0}=0.3 \sim 1.5 \mathrm{~mm}$ の範囲内で直線関係を有し, 利得 $Q=2.46$ である. $d_{0}=0.3 \mathrm{~mm}$ 以下で直線性がなくなるが, 乙れは容量一 電圧変換回路の出力が飽和するためである. 本装置に よる感度は $V / k d^{2}$ で表わされ, 試作したプローブで $d_{0}=0.5 \mathrm{~mm}, V=15 \mathrm{~V}$ のときに $2.52 \mathrm{mV} / \mu \mathrm{m}$ であ る. Fig. 20 は感度を $1 \mathrm{mV} / \mu \mathrm{m}$ に調節したときの 作動状態でのドリフト特性を示したものである. 短 時間ドリフトは約 $5 \mu \mathrm{V}$ であり，長時間ドリフトは $10 \mu \mathrm{V}$ 程度生じているが, これは振動振幅 $\Delta d$ に換 算すると $10 \mathrm{~nm}$ 程度で, 十分安定している. したが って $1 \mu \mathrm{m}$ 程度の振動振幅測定には十分利用できる.

Fig. 21 は $\left(\Delta d / d_{0}\right)$ 亿対する本測定法における誤差 を理論的に求めたもので，一般的に微小振幅に対して は $\left(\Delta d / d_{0}\right) \leqq 0.1$ で测定可能であるため $0.8 \%$ 以下の 誤差で測定できる. 本測定器の特性を調べるために用 いた装置を Fig. 22 に示した. 振動源として市販の スピーカを用い,コーン紙に電極をつけた円錐台を貼 り，プローブ面と対向させる．プローブー振動電極間 の間隔はマイクロメータにより調節した. Fig. 23 は レーザー干渉法と比較した結果である。横軸にスピー カ入力電圧 $e_{s p}$ を取り縦軸に振動振幅 $\Delta d$ を示した あのであり，レーザー干渉法とよく一致している.

Fig. 24(a)，（b ) は超音波加工用ニッケル振動子の振 幅を測定したむので, 振動子入力は $1 \mathrm{~kW}$, 振動周波 数は $16 \mathrm{kHz}$ である. 振動子には図に示したでとくそ れぞれ先端が円形段付きホーンと矩形段付きホーンが
取り付けられており, 測定器を $a, b$, のように走査し てホーン先端の各点における振動振幅 $\Delta d$ を測定した 結果である. 中央部分より端面に近くなるにつれて $\Delta d$ が減少しているようすが測定できた。

\section{5. むすび}

容量 一電圧変換回路を用いた簡易微小静電容量測定 装置とその変位測定, 振動振幅測定への応用について 述べた. 本方法は帰還容量 $C_{f}$ と入力信号電圧 $e_{i}$ に よって広範囲に 感度調節ができ, 一例として $C_{f}=10$ $\mathrm{pF}, e_{i}=10 \mathrm{~V}$ としたときの感度は. $1 \mathrm{~V} / \mathrm{pF}$ である. また可聴周波数で測定できるので簡単な電子回路で構 成できる利点を有している，本方法の応用として変位 測定装置および振動振幅測定装置の試作を行った結 果, 変位測定では $C_{f}=0.32 \mathrm{pF}, e_{i}=6.9 \mathrm{~V}$ のとき $51.6 \mathrm{mV} / \mu \mathrm{m}$, 振動振幅测定では $C_{f}=0.80 \mathrm{pF}, V=$ $15 \mathrm{~V}$ で $2.52 \mathrm{mV} / \mu \mathrm{m}$ の感度が得られ従来測定が困難 であった超音波加工用ホーンの場所による測定が可能 となった．本装置は容量変化法であるので取扱いが容 易な利点をむ有している.

終りに本研究に対し, 超音波加工用振動装置を提供 してくれた日本電子工業(株)の奥出顕造社長と熱心に 実験に協力してくれた本学大学院生照井孝君, 同じく 本学学生の長野康一君住対し感謝の意を表わします。

\section{参考 文 献}

1）菅野 允: 微小静電容量の測定と応用, 応用物理, 49-9, 905/912 (1980)

2）鈴木 昭, 菊池清明, 長野康一：容量変化法による簡易 変位計, 第 15 回 SICE 北海道支部学術講”演会予稿集, 32 (1983)

3）鈴木 昭, 菊池清明, 高橋文祥: 容量変化法に上る微小 振動振幅の測定, 第 21 回 SICE 学術講演会予禧集, 3815 (1982)

4）鈴木 昭, 菊池清明 : 簡易微小静電容量測定法之変位招 よび振動振幅測定への応用, 電気学会計測研究会資料, IM-83-31，47/54 (1983) 